\title{
Pre-Storage Application of Antioxidant Alleviates Chilling Injury and Maintains Quality of 'Valencia' Orange Fruits Stored at Low Temperature
}

\author{
M.A.A. Mohamed ${ }^{*}$, A.F. Abd El-khalek ${ }^{* *}$, H.G. Elmehrat ${ }^{* * *}$ \\ and Gehan A. Mahmoud* \\ *Fruit Handling Department, Horticulture Research Institute, \\ Agricultural Research Centre, ${ }^{* *}$ Horticulture Department, \\ Faculty of Agricultural, Tanta University and ${ }^{* * *}$ Organic \\ Agricultural, Central Lab., Agricultural Research Centre, \\ Cairo, Egypt.
}

\begin{abstract}
7 HE EFFECTS of postharvest antioxidant solutions on quality of 'Valencia' orange fruits under cold storage were studied. Fruits were soaked for 10 minutes in a solution of distilled water (control), salicylic acid (SA) $2 \mathrm{mM}$, ascorbic acid (AsA) 12 $\mathrm{mM}$, citric acid CA $20 \mathrm{mM}$, and their combinations. Fruits treated with these applications alone or in combination antioxidant solutions especially $2 \mathrm{mM}$ SA plus $12 \mathrm{mM}$ AsA or $20 \mathrm{mM}$ CA alleviated chilling injury index symptoms, reduced fruit weight loss percentage and decay incidence as well as increased the marketable percentage as compared to untreated fruits. Moreover, these treatments decreased loss of firmness, hue angle, lightness values and juice content of fruits. Furthermore, these applications reduced the activities of polyphenol oxidase (PPO) and pectinase (PE) enzymes beside enhanced the activity of peroxidase (POX) enzyme. In addition, orange fruits treated with antioxidant solutions especially $2 \mathrm{mM}$ SA in combination with $12 \mathrm{mM}$ AsA had the highest fruit contents of titratable acidity (TA) and ascorbic acid (AsA) and had least soluble solids content (SSC) and SSC/TA ratio than control during cold storage at $5^{\circ} \mathrm{C}$ plus one week shelf life at ambient temperature.
\end{abstract}

Keywords: Antioxidant, Salicylic, Ascorbic, Citric, Orange, Chilling injury, Fruit quality.

Citrus is the most economically and nutritionally important fruit crops in Egypt and other Mediterranean countries. Various citrus importing countries require quarantine security against Mediterranean fruit fly (Medfly) and fruit must be Medfly free. Cold quarantine treatments, which involve the exposure of fruit to near freezing temperatures $\left(1.1-2.2^{\circ} \mathrm{C}\right.$ ) for a period of 14-18 days (Powell, 2003) is a procedure accepted for Medfly disinfestations of citrus fruit by the regulatory agencies of the most importing citrus countries. Storage of citrus fruits below specific temperature leads to chilling injury (Lafuente \& Zacarias, 2006). Citrus fruit is known for its susceptibility to peel disorders at storage temperature below $10^{\circ} \mathrm{C}$ (Ben-Yehoshua et al., 2001). Chilling injury can be result from oxidative stress caused by reactive oxygen species (ROS), when it 
appears that super oxide, hydrogen peroxide and hydroxyl radical increased from scavenging capacity of tissues (Evans et al., 2005). ROS are highly reactive because they can interact with a number of cellular molecules and metabolites, thereby leading to a number of destructive processes causing cellular damage (Allen et al., 1997). Plant resistance to different stresses is mostly expressed by an increase in protective enzymes such as peroxidases and catalases. POX activity is expressed when plant tissue is subjected to stresses such as low temperature or pathogen infection (Yao \& Tian, 2005 and Xu \& Tian, 2008). The activity of peroxidase (POX) has also been thought to be related to the prevention of chilling damage, as they also use hydrogen peroxide (El-hilali et al., 2003). The increase in resistance of plants that had become acclimatized to low temperature was correlated with increased POX activity (Chongchatuporn et al., 2013 and Liu et al., 2014).

Antioxidants play an important role in protecting fruits from the oxidative damage inflicted by ROS, thus assuring quality and extending produce shelf life (Hodges, 2003). They are considering protecting tissue against ROS (Hodges, et al., 2004). Ascorbic acid (AsA) is a major water-soluble antioxidant in plants and it is one of the most abundant plant antioxidants. Moreover, AsA is one of the most powerful antioxidants (Smirnoff, 2000). AsA maintained the cell plasma membranes structure, less oxidative reactions accumulations and effectively controlled the enzymatic browning and cell death of fruits (Linster \& Clarke, 2008). The application of exogenous organic acids such as citric acid and salicylic acid has been found to affect fruit quality and induce stress tolerance (Huang et al., 2008 and Shoor, 2010). These organic acids mainly function in maintaining the ability to inhibit $\mathrm{O}_{2}^{-}$accumulation, delaying hydrogen peroxide decrease and enhancing antioxidant enzyme activities with an increase in the expression of senescence related proteins or defense proteins to keeps the fruit in good quality during storage (Huang et al., 2008; Ding et al., 2009 and Tareen et al., 2012a, b).

Salicylic acid (SA) is a natural and safe simple phenolic compound, exhibits a high potential in controlling postharvest losses of horticultural crops (Asghari \& Aghdam, 2010). SA is also a signaling molecule, which induces biosynthesis of defense compounds such as poly phenols and pathogenesis related proteins (Delaney et al., 1994 and Yao \& Tian, 2005). Moreover, SA involved in activation of the stress induced antioxidant system when plants are exposed to stress (Huang et al., 2008 and Xu \& Tian, 2008). SA treatment could be used to reduce deterioration and chilling injury symptoms in some fruits (Sayyari et al., 2009 and Yang et al., 2012). Postharvest soaking in AsA controlled the chilling injury symptoms in mango fruits (Lo'ay, 2010 and Samaan et al., 2011) and 'Eureka' lemon fruits (Abd El-khalek, 2012 and El-Abbasy et al., 2013) during cold storage. In addition, immersing pineapple fruits in $5 \mathrm{mM}$ SA reduced the internal browning incidence ( $\mathrm{Lu}$ et al., 2011). Moreover, postharvest application with SA at $2 \mathrm{mM}$ concentration was highly effective in reducing chilling injury 
incidence and decay of cold stored pomegranate fruits at $2^{\circ} \mathrm{C}$ for three months (Sayyari et al., 2009 and Sayyari et al., 2011).

In this study, we aimed to examine the effects of postharvest treatments with antioxidant of salicylic acid, ascorbic acid and citric acid solutions separately or in combinations on the induction of cold tolerance and maintaining quality of 'Valencia' orange fruits during cold storage at $5^{\circ} \mathrm{C}$ plus one week at ambient temperature $\left(18-23^{\circ} \mathrm{C}\right)$ as marketing period.

\section{Materials and Methods}

The present study was carried out during two successive seasons 2014 and 2015 on 'Valencia' orange fruits. Commercially mature fruits were picked randomly from a private orchard at El-Behera Governorate, Egypt. 'Valencia' orange trees were about 23 years old, grafted on 'Volkamariana' rootstock and planted at $5 \times 5$ meters, irrigated by drip system and subjected to all ideal agricultural practices. The fruits were picked from almost similar trees, apparently uniform in size and free of visible symptoms of infection. After that, fruits were transported to postharvest laboratory at Horticulture Research Institute, Agriculture Research Center, Giza governorate. Once arrival to the laboratory, orange fruits were thoroughly cleaned with tap water to remove dirt and held for $24 \mathrm{hr}$ at room temperature. After that, the fruits were sorted based on uniformity in size, colour and freedom from defects.

Fruits were randomly divided into seven treatments, each treatment included 108 fruits (6 storage periods x 3 replication x 6 fruits). The fruits were soaked for ten minutes in the following treatments: distilled water, used as the control, salicylic acid (SA) at $2 \mathrm{mM}$, ascorbic acid (AsA) at $12 \mathrm{mM}$, citric acid (CA) at $20 \mathrm{mM}, \mathrm{SA}$ at $2 \mathrm{mM}+\mathrm{AsA}$ at $12 \mathrm{mM}, \mathrm{SA}$ at $2 \mathrm{mM}+\mathrm{CA}$ at $20 \mathrm{mM}$ and AsA at $12 \mathrm{mM}+\mathrm{CA}$ at $20 \mathrm{mM}$. Tween-80 at $0.05 \%(\mathrm{v} / \mathrm{v})$ was added in each solution to improve wettability and adherence to oranges surface. After soaking treatments, all fruits were dried by electric fans for one hour and then packaged in perforated polyethylene bags. Each treatment was packaged in carton boxes and each box consist of 12 fruits. Then all treatments stored at $5 \pm 1{ }^{\circ} \mathrm{C}$ and $85-90 \%$ relative humidity $(\mathrm{RH})$ for 15 weeks. Fruit physical and chemical characteristics were determined at harvest time and at 3 weeks intervals of cold storage period plus one week at ambient temperature $18-23^{\circ} \mathrm{C}$ and $50-65 \% \mathrm{RH}$ as a shelf life period to simulate a marketing period. While, the activities of peroxidase (POX), polyphenol oxidase (PPO) and pectinase (PE) enzymes were determined at 0,3 , 9 and 15 weeks of cold storage period followed by one week shelf life at ambient temperature.

\section{Measurements of fruit physical and chemical characteristics}

Weight loss percentage was calculated by the following equation [(initial fruit weight - fruit weight at examination date) / (initial fruit weight) $] \times 100$. 
Chilling injury index (CI): The visible symptoms of chilling injury on fruits were measured on five fruits at three replicates per treatment. Peel disorders were evaluated based on following hedonic scale $0=$ no injury, $1=$ light injury (less than $5 \%$ of peel area affected), $2=$ moderate injury $(6-25 \%$ of peel area affected), $3=$ severe injury (26-50\% of peel area affected) and $4=$ very severe injury (more than $50 \%$ of peel area affected). The CI was calculated according to the following formula: $\mathrm{CI}=\sum$ (number of fruit with chilling $\mathrm{x}$ score of severity) / total number of fruit assessed.

Decayed fruit percentage was determined as follow [(number of decayed fruits at examination date) / (initial number of fruits)] $\times 100$.

Marketable fruit percentage was calculated by the following formula [(sound fruits at examination date) / (initial fruit weight) $\times 100$.

Fruit colour was measured using a Minolta CR-400 Chroma Meter (Minolta Co. Itd. Osaka, Japan). The measurements of skin colour and gloss were expressed in chromaticity values of hue angle $\left(\mathrm{h}^{\circ}\right)$ and lightness (L), respectively. Three readings were taken at different locations of each orange fruit during each data observation (McGuire, 1992 and Voss, 1992).

Fruit firmness of the peel was assessed by using lfra texture analyzer instrument. The force required to penetrate $1 \mathrm{~cm}$ inside the fruit using a needle probe diameter of $5 \mathrm{~mm}$ was measured. The machine was set with peak mode and speed of $0.3 \mathrm{~mm} / \mathrm{sec}$. Readings were recorded on the two opposite sides of the orange fruit and the results were expressed as the resistance force to the penetrating tester in units of pressure $\mathrm{g} / \mathrm{cm}^{2}$ (Watkins \& Harman, 1981).

Fruit juice content was measured by squeezing six fruits for each treatment represent three replicates and then juice percentage was calculated $(w / w)$.

Fruit juice content of ascorbic acid (AsA) was determined according to method of adopting the procedure described by AOAC (1990) and was calculated as $\mathrm{mg} / 100 \mathrm{ml}$ juice.

Fruit juice soluble solids content (SSC) was determined by hand refractometer, 0-32 scale (ATAGO N-1 $1_{\mathrm{E}}$, Japan) and expressed in ${ }^{\circ}$ Brix after making the temperature correction at $20^{\circ} \mathrm{C}$ according to AOAC (1990).

Fruit juice content of titratable acidity (TA) was measured by titration as mentioned by AOAC (1990) and was calculated as grams of citric acid/100 ml juice.

Fruit juice SSC/TA ratio was calculated from the values recorded for fruit juice SSC and TA percentages determined.

Egypt. J. Hort. Vol. 43, No. 1 (2016) 


\section{Enzyme activities}

0.5 gram of fresh orange peel was homogenized by using a mortar and pestle with $0.1 \mathrm{M}$ buffer of phosphate at $4^{\circ} \mathrm{C}(\mathrm{pH}=6.5)$ and stirred for 20 minutes. The suspension obtained was filtered through one piece of muslin cloth and afterwards centrifuged at $18,000 \times \mathrm{g}$ for 15 minutes, $4^{\circ} \mathrm{C}$. Polyphenol oxidase (PPO) enzyme was measured as mentioned by Fernandez et al. (2011), while peroxidase (POX) and pectinase (PE) enzymes were determined according to Horwitz et al. (1975). The activities of these enzymes were expressed as units per gram fresh weight $\left(\mathrm{U} \mathrm{g}^{-1} \mathrm{fW}\right)$.

\section{Statistical analysis}

This experiment was arranged in a completely randomized design having three replications (Steel et al., 1997) and consisting of two factors (antioxidant treatments and storage periods). This experiment was analysis as factorial. Data calculated as percentage were transformed to arcsine of square root before statistical analysis and non-transformed means are shown. The effects of antioxidant treatments and cold storage periods on different characteristics were analyzed statistically by analysis of variance (ANOVA) using the MSTAT-C statistical package (M-STAT, 1993). Comparisons between means were done by Duncan's multiple range tests (DMRT) at probability $\leq 0.05$.

\section{Results and Discussions}

Effect of antioxidant applications of salicylic acid (SA), ascorbic acid (AsA) and citric acid (CA) solutions on physical and chemical characteristics of 'Valencia' orange fruit during cold storage

Fruit weight loss percentage, chilling injury index, decay incidence and marketable fruit percentage

Data presented in Tables 1, 2, 3 and 4 clearly indicated that, weight loss, chilling index and decayed fruit percentage increased while marketable fruit percentage gradually and significantly decreased with prolonging of cold storage period at $5^{\circ} \mathrm{C}$ followed by one week shelf life at $18-23^{\circ} \mathrm{C}$ in the two seasons.

Data also cleared that, all pre-storage treatments of antioxidant significantly decreased weight loss percentage, chilling injury index and decay incidence with an increase in marketable percentage of 'Valencia' orange fruits as compared to untreated fruits (control) during storage in both seasons under this investigation. Moreover, it is clear that, treatments of $2 \mathrm{mM}$ of SA in combination with $12 \mathrm{mM}$ of AsA followed by $2 \mathrm{mM} \mathrm{SA}$ in combination with $20 \mathrm{mM}$ citric acid of oranges were more effective in decreasing loss in fruit weight and alleviating chilling injury symptoms, reducing decay incidence and increasing marketable fruit percentage than other treatments in both seasons. 
TABLE 1. Effect of antioxidant applications of salicylic acid (SA), ascorbic acid (AsA) and citric acid (CA) solutions on weight loss percentage of 'Valencia' orange fruits during cold storage at $5^{\circ} \mathrm{C}$ followed by one week at $18-23^{\circ} \mathrm{C}$ as marketing period

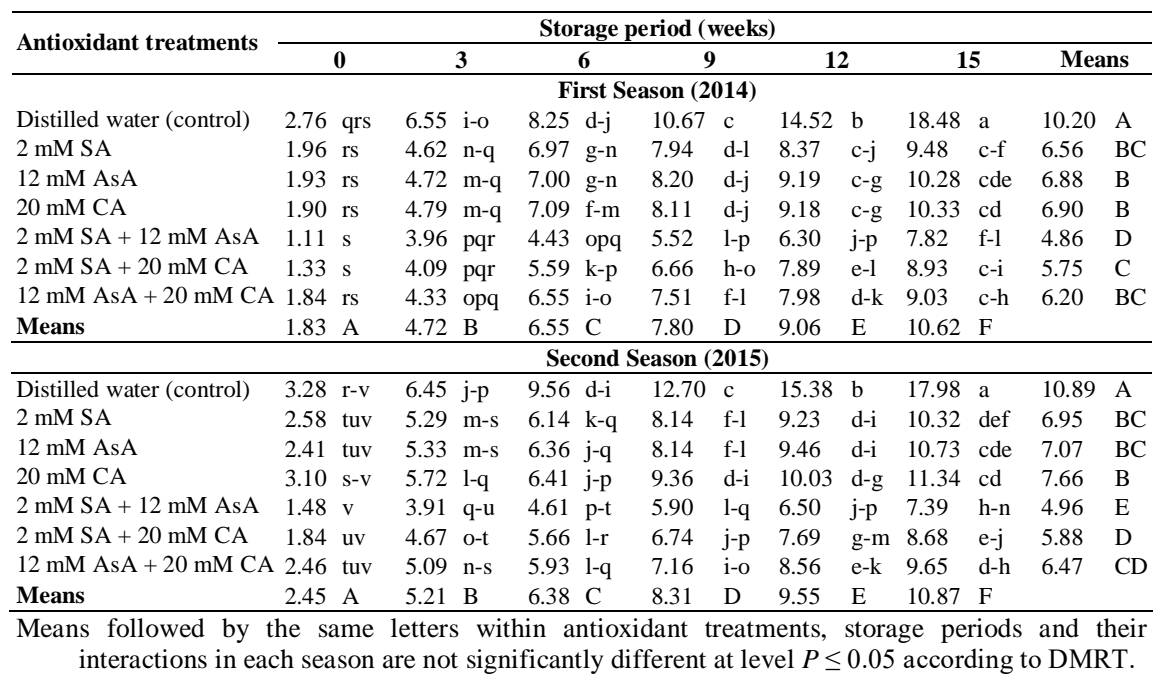

TABLE 2. Effect of antioxidant applications of salicylic acid (SA), ascorbic acid (AsA) and citric acid (CA) solutions on chilling injury index of 'Valencia' orange fruits during cold storage at $5^{\circ} \mathrm{C}$ followed by one week at $18-23^{\circ} \mathrm{C}$ as marketing period

\begin{tabular}{|c|c|c|c|c|c|c|c|c|c|c|c|c|c|c|}
\hline \multirow{2}{*}{ Antioxidant treatments } & \multicolumn{12}{|c|}{ Storage period (weeks) } & \multirow{2}{*}{\multicolumn{2}{|c|}{ Means }} \\
\hline & \multicolumn{2}{|c|}{$\mathbf{0}$} & \multicolumn{2}{|c|}{3} & \multicolumn{2}{|c|}{6} & \multicolumn{2}{|c|}{9} & \multicolumn{2}{|c|}{12} & \multicolumn{2}{|c|}{15} & & \\
\hline & & & & & Firs & tSea & son $(2$ & 014) & & & & & \multicolumn{2}{|c|}{ Hitcans } \\
\hline Distilled water (control) & 0.00 & $\mathrm{f}$ & 0.73 & $\operatorname{def}$ & 1.03 & def & 2.37 & $\mathrm{bc}$ & 3.10 & $a b$ & 3.87 & a & 1.87 & A \\
\hline $2 \mathrm{mM}$ SA & 0.00 & $\mathrm{f}$ & 0.00 & $f$ & 0.00 & $\mathrm{f}$ & 0.60 & def & 0.90 & def & 1.03 & def & 0.43 & $\mathrm{BCD}$ \\
\hline $12 \mathrm{mM}$ AsA & 0.00 & $\mathrm{f}$ & 0.00 & $f$ & 0.00 & $\mathrm{f}$ & 0.90 & def & 1.20 & def & 1.47 & cde & 0.60 & $\mathrm{BC}$ \\
\hline $20 \mathrm{mM} \mathrm{CA}$ & 0.00 & $\mathrm{f}$ & 0.00 & f & 0.30 & ef & 1.03 & def & 1.33 & cde & 1.63 & $\mathrm{~cd}$ & 0.70 & B \\
\hline $2 \mathrm{mM} \mathrm{SA}+12 \mathrm{mM}$ AsA & 0.00 & $\mathrm{f}$ & 0.00 & $f$ & 0.00 & $\mathrm{f}$ & 0.00 & f & 0.00 & $\mathrm{f}$ & 0.43 & def & 0.07 & $\mathrm{D}$ \\
\hline $2 \mathrm{mM} \mathrm{SA}+20 \mathrm{mM} \mathrm{CA}$ & 0.00 & $\mathrm{f}$ & 0.00 & f & 0.00 & $\mathrm{f}$ & 0.00 & f & 0.30 & ef & 0.60 & def & 0.13 & $\mathrm{CD}$ \\
\hline $12 \mathrm{mM} \mathrm{AsA}+20 \mathrm{mM} \mathrm{CA}$ & 0.00 & $\mathrm{f}$ & 0.00 & $f$ & 0.00 & $\mathrm{f}$ & 0.43 & def & 0.60 & def & 0.90 & def & 0.33 & $\mathrm{BCD}$ \\
\hline \multirow[t]{2}{*}{ Means } & 0.00 & $\mathrm{C}$ & 0.10 & $\mathrm{C}$ & 0.20 & $\mathrm{C}$ & 0.77 & $\mathrm{~B}$ & 1.07 & $\mathrm{AB}$ & 1.43 & $\mathrm{~A}$ & & \\
\hline & \multicolumn{12}{|c|}{ Second Season $(2015)$} & & \\
\hline Distilled water (control) & 0.00 & $\mathrm{~g}$ & 0.90 & d-g & 1.47 & de & 2.80 & $\mathrm{bc}$ & 3.40 & $\mathrm{ab}$ & 4.13 & $\mathrm{a}$ & 2.13 & A \\
\hline $2 \mathrm{mM}$ SA & 0.00 & $\mathrm{~g}$ & 0.00 & $\mathrm{~g}$ & 0.00 & g & 0.13 & fg & 0.60 & efg & 1.20 & def & 0.33 & $\mathrm{BC}$ \\
\hline $12 \mathrm{mM}$ AsA & 0.00 & $\mathrm{~g}$ & 0.00 & $\mathrm{~g}$ & 0.00 & $\mathrm{~g}$ & 0.30 & fg & 0.73 & efg & 1.47 & de & 0.43 & $\mathrm{BC}$ \\
\hline $20 \mathrm{mM} \mathrm{CA}$ & 0.00 & g & 0.00 & $\mathrm{~g}$ & 0.00 & $\mathrm{~g}$ & 0.43 & efg & 1.03 & d-g & 1.93 & $\mathrm{~cd}$ & 0.57 & $\mathrm{~B}$ \\
\hline $2 \mathrm{mM} \mathrm{SA}+12 \mathrm{mM}$ AsA & 0.00 & $\mathrm{~g}$ & 0.00 & $\mathrm{~g}$ & 0.00 & $\mathrm{~g}$ & 0.00 & $\mathrm{~g}$ & 0.00 & $\mathrm{~g}$ & 0.60 & efg & 0.10 & $\mathrm{C}$ \\
\hline $2 \mathrm{mM} \mathrm{SA}+20 \mathrm{mM} \mathrm{CA}$ & 0.00 & $\mathrm{~g}$ & 0.00 & $\mathrm{~g}$ & 0.00 & g & 0.00 & $\mathrm{~g}$ & 0.00 & $\mathrm{~g}$ & 0.73 & efg & 0.13 & $\mathrm{C}$ \\
\hline $12 \mathrm{mM} \mathrm{AsA}+20 \mathrm{mM} \mathrm{CA}$ & 0.00 & g & 0.00 & g & 0.00 & $\mathrm{~g}$ & 0.13 & fg & 0.43 & efg & 1.03 & d-g & 0.27 & $\mathrm{BC}$ \\
\hline Means & 0.00 & $\mathrm{D}$ & 0.13 & $\mathrm{D}$ & 0.20 & $\mathrm{CD}$ & 0.57 & $\mathrm{BC}$ & 0.90 & $\mathrm{~B}$ & 1.60 & $\mathrm{~A}$ & & \\
\hline
\end{tabular}

Means followed by the same letters within antioxidant treatments, storage periods and their interactions in each season are not significantly different at level $P \leq 0.05$ according to DMRT. 
PRE-STORAGE APPLICATION OF ANTIOXIDANT ALLEVIATES...

TABLE 3. Effect of antioxidant applications of salicylic acid (SA), ascorbic acid (AsA) and citric acid (CA) solutions on decay percentage of 'Valencia' orange fruits during cold storage at $5^{\circ} \mathrm{C}$ followed by one week at $18-23{ }^{\circ} \mathrm{C}$ as marketing period

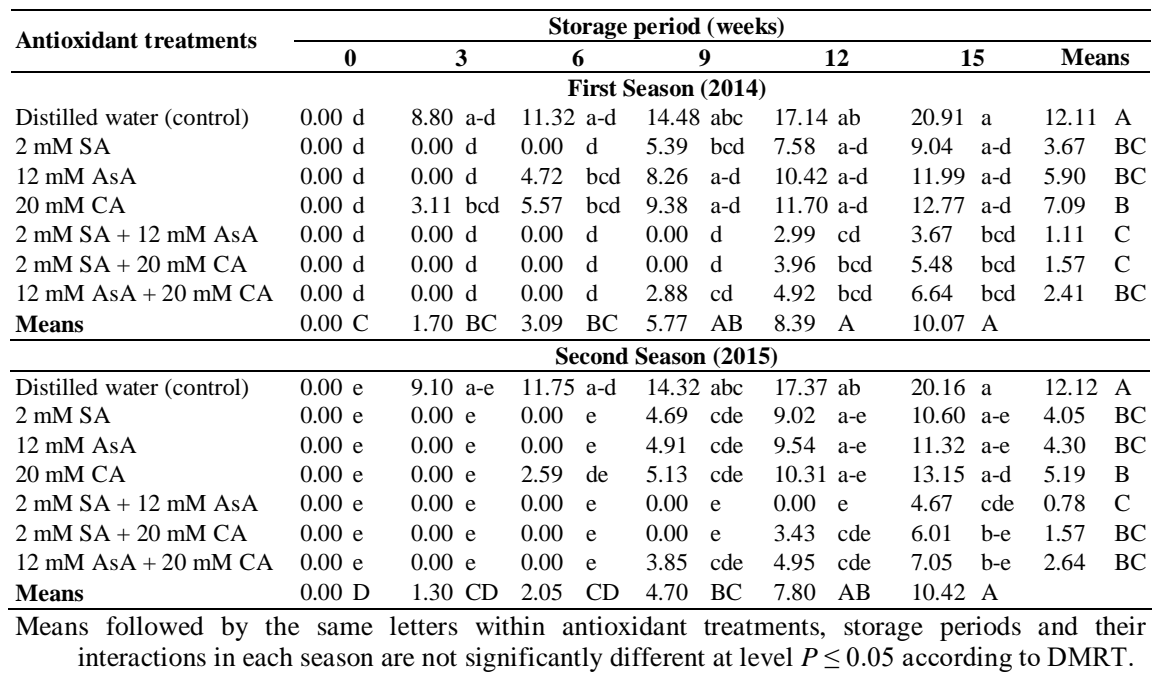

TABLE 4. Effect of antioxidant applications of salicylic acid (SA), ascorbic acid (AsA) and citric acid (CA) solutions on marketable percentage of 'Valencia' orange fruits during cold storage at $5^{\circ} \mathrm{C}$ followed by one week at $18-23^{\circ} \mathrm{C}$ as marketing period

\begin{tabular}{|c|c|c|c|c|c|c|c|}
\hline \multirow{2}{*}{ Antioxidant treatments } & \multicolumn{6}{|c|}{ Storage period (weeks) } & \multirow[b]{2}{*}{ Means } \\
\hline & 0 & 3 & 6 & 9 & 12 & 15 & \\
\hline \multicolumn{8}{|c|}{ First Season (2014) } \\
\hline Distilled water (control) & $97.24 \mathrm{ab}$ & 84.65 a-e & $73.77 \mathrm{c}-\mathrm{f}$ & $61.52 \mathrm{f}$ & $41.68 \mathrm{~g}$ & $27.27 \mathrm{~g}$ & $64.36 \mathrm{D}$ \\
\hline $2 \mathrm{mM}$ SA & $98.04 \mathrm{a}$ & $95.38 \mathrm{a}-\mathrm{d}$ & $93.03 \mathrm{a}-\mathrm{d}$ & 86.67 a-d & 84.05 a-e & 74.82 b-f & $88.67 \mathrm{ABC}$ \\
\hline $12 \mathrm{mM}$ AsA & $98.07 \mathrm{a}$ & $95.29 \mathrm{a}-\mathrm{d}$ & $88.28 \mathrm{a}-\mathrm{d}$ & $83.54 \mathrm{a}-\mathrm{f}$ & $73.73 \mathrm{c}-\mathrm{f}$ & 64.40 ef & $83.89 \mathrm{BC}$ \\
\hline $20 \mathrm{mM} \mathrm{CA}$ & $98.10 \mathrm{a}$ & 92.11 a-d & 87.34 a-d & 82.51 a-f & $72.46 \mathrm{def}$ & 63.56 ef & $82.68 \mathrm{C}$ \\
\hline $2 \mathrm{mM} \mathrm{SA}+12 \mathrm{mM} \mathrm{AsA}$ & $98.89 \mathrm{a}$ & $96.04 \mathrm{abc}$ & $95.57 \mathrm{abc}$ & 94.48 a-d & 90.71 a-d & 88.50 a-d & $94.03 \mathrm{~A}$ \\
\hline $2 \mathrm{mM} \mathrm{SA}+20 \mathrm{mM} \mathrm{CA}$ & $98.67 \mathrm{a}$ & $95.91 \mathrm{abc}$ & 94.41 a-d & 93.34 a-d & 88.16 a-d & 78.92 a-f & $91.57 \mathrm{AB}$ \\
\hline $12 \mathrm{mM} \mathrm{AsA}+20 \mathrm{mM} \mathrm{CA}$ & $98.16 \mathrm{a}$ & $95.67 \mathrm{abc}$ & $93.45 \mathrm{a}-\mathrm{d}$ & $89.61 \mathrm{a}-\mathrm{d}$ & $87.10 \mathrm{a}-\mathrm{d}$ & $77.67 \mathrm{a}-\mathrm{f}$ & $90.28 \mathrm{ABC}$ \\
\hline Means & $98.17 \mathrm{~A}$ & $93.58 \mathrm{AB}$ & $89.41 \mathrm{BC}$ & $84.52 \mathrm{C}$ & $76.84 \mathrm{D}$ & $67.88 \mathrm{E}$ & \\
\hline \multicolumn{8}{|c|}{ Second Season (2015) } \\
\hline Distilled water (control) & $96.72 \mathrm{ab}$ & 84.45 a-e & 72.02 ef & $52.98 \mathrm{~g}$ & $33.91 \mathrm{~h}$ & $21.85 \mathrm{~h}$ & $60.32 \mathrm{D}$ \\
\hline $2 \mathrm{mM}$ SA & $97.42 \mathrm{ab}$ & $94.71 \mathrm{ab}$ & $93.86 \mathrm{ab}$ & 87.17 a-e & 81.75 a-e & 72.41 ef & $87.89 \mathrm{BC}$ \\
\hline $12 \mathrm{mM}$ AsA & $97.59 \mathrm{ab}$ & $94.67 \mathrm{ab}$ & $93.64 \mathrm{ab}$ & 86.95 a-e & $81.00 \mathrm{~b}-\mathrm{e}$ & $64.61 \mathrm{fg}$ & $86.41 \mathrm{C}$ \\
\hline $20 \mathrm{mM} \mathrm{CA}$ & $96.90 \mathrm{ab}$ & $94.28 \mathrm{ab}$ & $91.00 \mathrm{abc}$ & 85.51 a-e & 73.00 def & $62.18 \mathrm{fg}$ & $83.81 \mathrm{C}$ \\
\hline $2 \mathrm{mM} \mathrm{SA}+12 \mathrm{mM} \mathrm{AsA}$ & $98.52 \mathrm{a}$ & $96.09 \mathrm{ab}$ & $95.39 \mathrm{ab}$ & $94.10 \mathrm{ab}$ & $93.50 \mathrm{ab}$ & 87.94 a-e & $94.26 \mathrm{~A}$ \\
\hline $2 \mathrm{mM} \mathrm{SA}+20 \mathrm{mM} \mathrm{CA}$ & $98.16 \mathrm{a}$ & $95.33 \mathrm{ab}$ & $94.34 \mathrm{ab}$ & $93.26 \mathrm{ab}$ & 88.88 a-d & 85.31 a-e & $92.55 \mathrm{AB}$ \\
\hline $12 \mathrm{mM} \mathrm{AsA}+20 \mathrm{mM} \mathrm{CA}$ & $97.54 \mathrm{ab}$ & $94.91 \mathrm{ab}$ & $94.07 \mathrm{ab}$ & 88.99 a-d & 86.49 a-e & $76.63 \mathrm{c}-\mathrm{f}$ & $89.77 \mathrm{ABC}$ \\
\hline Means & $97.55 \mathrm{~A}$ & $93.49 \mathrm{AB}$ & $90.62 \mathrm{~B}$ & $84.14 \mathrm{C}$ & $76.93 \mathrm{D}$ & $67.28 \mathrm{E}$ & \\
\hline
\end{tabular}
interactions in each season are not significantly different at level $P \leq 0.05$ according to DMRT. 
The loss in weight of fresh fruits and vegetables is mainly due to the loss of water caused by transpiration and respiration processes (Cohen et al., 1994 and Medeira et al., 1999). In addition, SA and AsA treatments are contributing to the detoxification of active oxygen (Ding et al., 2007 and Huang et al., 2008). In this study, reducing decay percentage of 'Valencia' orange fruits with treated antioxidant solutions could be attributed to the increase in activity of POX enzyme and the decrease in activities of PPO and PE enzymes during cold storage.

These results are in harmony with those mentioned by Zheng \& Zhang (2004) on 'Ponkan' mandarins and Abd El-khalek (2012) and El-Abbasy et al. (2013) on 'Eureka' lemons. They reported that, SA and AsA applications reduced fruit weight loss percentage than control. Moreover, these results are in agreement with the outcomes of Sayyari et al. (2009) and Sayyari et al. (2011) on pomegranates, Lo'ay (2010) and Samaan et al. (2011) on mangoes and Lu et al. (2011) on 'Winter' pineapples. They mentioned that, SA and AsA treatments alleviated the chilling injury symptoms of fruits in comparison to control.

In addition, our results in the peresent study are in agreement with the outcome of Sayyari et al. (2009) on pomegranates, Lo'ay (2010) on mangoes, Aghdam et al. (2011) on kiwifruits, Abd El-khalek (2012) and El-Abbasy et al. (2013) on 'Eureka' lemons and Tareen et al. (2012a, b) on peaches. They mentioned that, SA and AsA applications significantly lowered decay incedince of the fruits as compared to untreated fruits.

\section{Fruit firmness, gloss (lightness), colour (hue angle) and juice content}

Skin colour development represented as hue angle value (greenish yellow, around 75 and yellow, around 60) and gloss represented as lightness. Data displayed in Figures 1 and 2 shown that, fruit firmness, lightness and juice content gradually and significantly decreased with prolonging of cold storage period at $5^{\circ} \mathrm{C}$ followed by one week shelf life at $18-23^{\circ} \mathrm{C}$ in the two seasons. On the other side, data also indicated that, fruit colour represented as hue angle significantly changed from greenish yellow to yellow at the end of storage period in the two seasons in this work. Data also mentioned that, all postharvest treatments of oranges significantly reduced the decreasing rate of fruit firmness, hue angle, lightness and juice content during storage compared with untreated fruits during the two seasons in this investigation.

Moreover, data cleared that, 'Valencia' orange fruits treated with $2 \mathrm{mM} \mathrm{SA}$ in combination with $12 \mathrm{mM}$ AsA followed by $2 \mathrm{mM} \mathrm{SA}$ in combination with 20 $\mathrm{mM}$ CA were superior in maintaining firmness, lightness and juice content as well as delaying skin colour development as compared to the other treatments in the two seasons in this work.

The loss of fruit firmness are associated with changes in cell wall mechanical strength during storage (Valero \& Serrano, 2010). Loss of fruit firmness starts 
with the conversion of insoluble protopectin into water soluble pectin by breakdown of the middle lamellae, which is intimately related to hydrolytic enzyme, so rigidity of cell walls was reduced and led to fruit softening (Pressey \& Avants, 1973). In addition, firmness of citrus fruit depends primarily on the weight loss rate (Ben-Yehoshua et al., 1983).

(A)

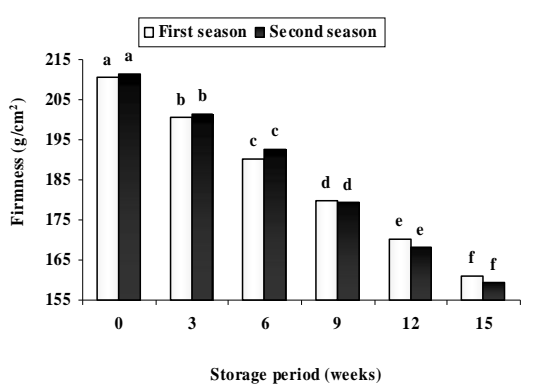

(C)

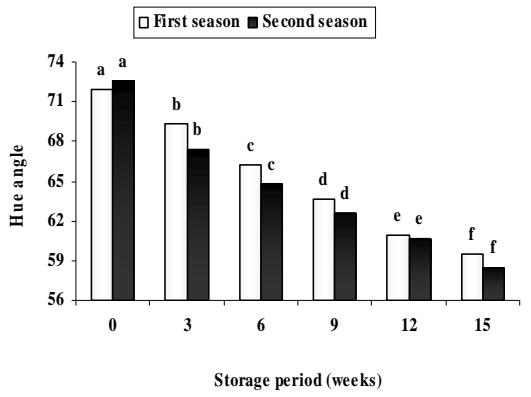

(B)

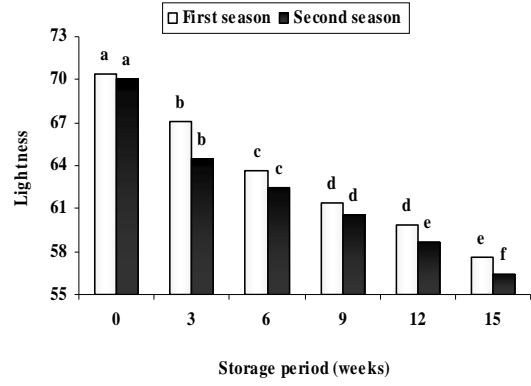

(D)

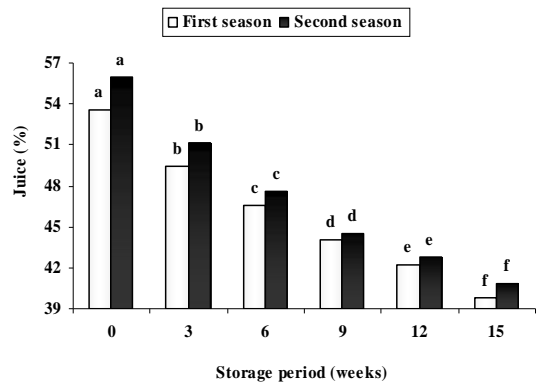

Figure 1. Effect of storage period on firmness (A), gloss represented as lightness (B), colour represented as hue angle $(C)$ and juice percentage $(D)$ of 'Valencia' orange fruits during cold storage at $5^{\circ} \mathrm{C}$ followed by one week at $18-23^{\circ} \mathrm{C}$ as marketing period.

Different letters indicate significant differences between storage periods according to DMRT at $P \leq 0.05$.

These results indicated that, 'Valencia' orange fruits treated with $2 \mathrm{mM}$ SA with $12 \mathrm{mM}$ AsA treatment had less weight loss and high firmness. This is because SA and AsA treatments could be inhibited the activity of hydrolytic enzyme and reduced respiration rate as reported by Lo'ay, (2005) and Yao \& Tian (2005). Our result in this investigation were supported by the findings of Aghdam et al. (2011) on kiwifruit fruits, Samaan et al. (2011) on mangoes, Sayyari et al. (2011) on pomegranates and Tareen et al. (2012a, b) on peaches. They mentioned that, the immersing fruits in SA and AsA solution decresed loss fruit firmness during cold storage. Meanwhile, these results are in line with the findings of Delwiche \& Baumgardner (1983). They reported that, water loss from the surface of peach fruit caused decreased luminosity. Moreover, our 
results are in agreement with the outcomes of Lo'ay (2010) and Samaan et al. (2011) on mangoes, Abd El-khalek (2012) and El-Abbasy et al. (2013) on lemons and Tareen et al. (2012a, b) on peaches. They illustrated that, immersing fruits in SA or AsA solution delayed colour development and maintained fruits lightness during cold storage. In addition, our results are supported by the findings of Abd El-khalek (2012) and El-Abbasy et al. (2013). They mentioned that, juice content of lemon fruits increased by treated with AsA treatment as compared to untreated fruits during cold storage period.

(A)

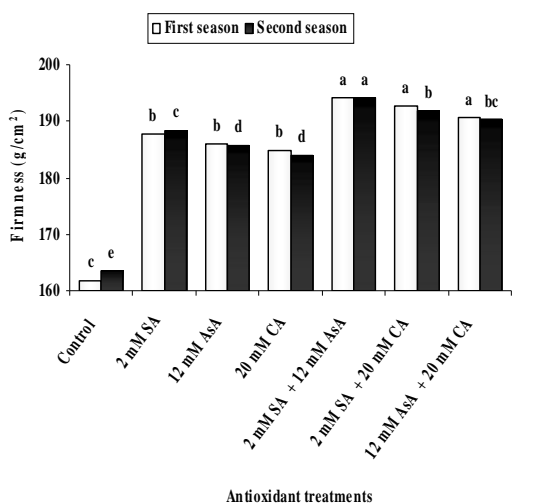

(C)

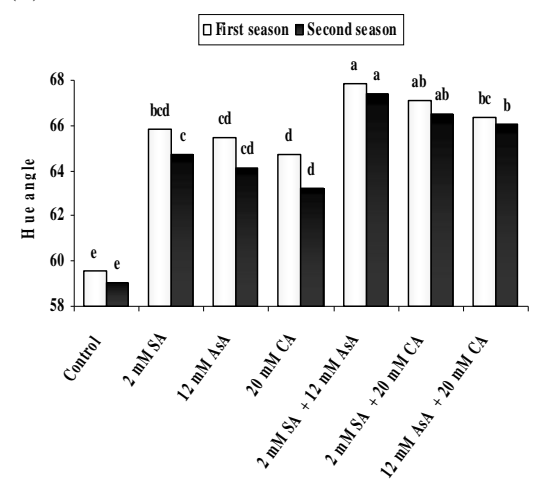

Antioxidant treatments
(B)

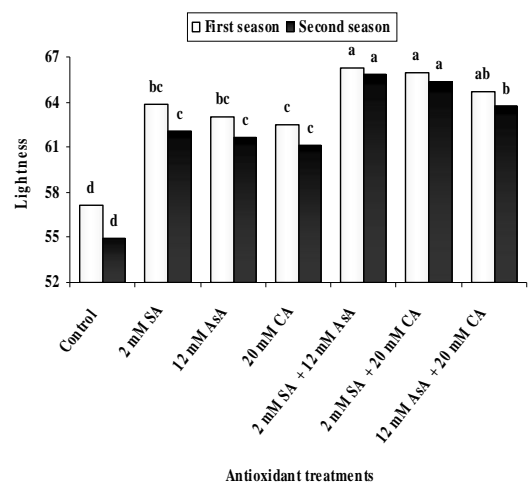

(D)

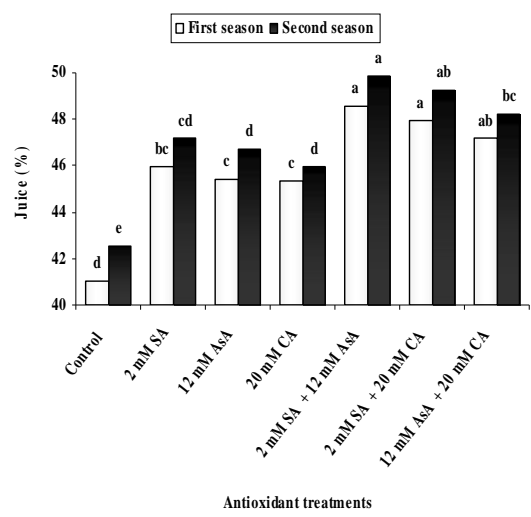

Figure 2. Effect of antioxidant applications of salicylic acid (SA), ascorbic acid (AsA) and citric acid (CA) solutions on firmness (A), gloss represented as lightness (B), colour represented as hue angle (C) and juice percentage (D) of 'Valencia' orange fruits during cold storage at $5^{\circ} \mathrm{C}$ followed by one week at $18-23^{\circ} \mathrm{C}$ as marketing period.

Different letters indicate significant differences between antioxidant treatments according to DMRT at $P \leq 0.05$.

Egypt. J. Hort. Vol. 43, No. 1 (2016) 
Fruit activities of peroxidase (POX), polyphenol oxidase (PPO) and pectinase $(P E)$ enzymes

Our results in Figure 3 showed that, the activities of POX, PPO and PE enzymes in the peel of 'Valencia' orange fruits gradually and significantly increased with prolonging of cold storage period at $5^{\circ} \mathrm{C}$ followed by one week shelf life at $18-23^{\circ} \mathrm{C}$ in both seasons in this study. An increase in activity of POX enzyme was observed during exposure of intact plants to low temperature (Xu \& Tian, 2008; Chongchatuporn et al., 2013 and Liu et al., 2014). In this study, antioxidant treatments were observed higher activity of POX enzyme than untreated fruits. Fruit with chilling injury had an abnormality in the cell membrane and caused the cell damage, which was a consequence of the accumulation of PPO in the cell (Paull \& Rohrbach, 1985).

In this experiment, the activities of POX and PPO enzymes were very low at harvest date in fruits of all treatments. The application of antioxidant treatments showed an increment in activity of POX enzyme and an decrease in activity of PPO enzyme especially application of $2 \mathrm{mM}$ SA in combination with $12 \mathrm{mM}$ AsA as compared to the untreated fruits (control) in the two seasons. The result indicates that, the activities of POX and PPO enzymes might be determines the higher tolerance to chilling injury in 'Valencia' orange fruits.

Moreover, the application of antioxidant treatments especially $2 \mathrm{mM}$ SA in combination with $12 \mathrm{mM}$ AsA treatment may be helpful for minimizing the utilization of antioxidants used for the scavenging of the free radicals. Senescence or stress condition coincided with membrane damage in fruits (Mayer, 1987). It was proposed that, the increase in the activity of POX enzyme and the decrease in activity of PPO enzyme that are intimately related to the lowest chilling injury were generally consequence of the system ability to delay senescence of fruits during cold storage and ultimately increased marketable fruits. Our results are in agreement with the findings of El-hilali et al. (2003) on mandarins, Huang et al. (2008) on oranges and Ding et al. (2009) and Tareen et al. $(2012 \mathrm{a}, \mathrm{b})$ on peaches. They reported that, pre-storage treatment of SA prolonged postharvest life of fruits and maintained beneficial antioxidant activity as well as effectively lowered the activity of PPO enzyme at low storage temperature.

Data also cleared that, the activity of PE enzyme significantly reduced by immersed fruits in antioxidant solutions as compared to untreated fruits. Moreover, it is clear that, immersed fruits in antioxidant solutions of $2 \mathrm{mM} \mathrm{SA}$ in combination with $12 \mathrm{mM}$ AsA followed by $2 \mathrm{mM}$ SA in combination with 20 mM CA were significantly lowered the activity of PE enzyme and had slower softening process in 'Valencia' orange fruits as compared to the other treatments in the two seasons. In this study, SA and AsA could be inhibited cell wall hydrolytic enzymes and reduced respiration rate as reported by Lo'ay (2005) on mangoes and Yao \& Tian (2005) on sweet cherry. 
(A)

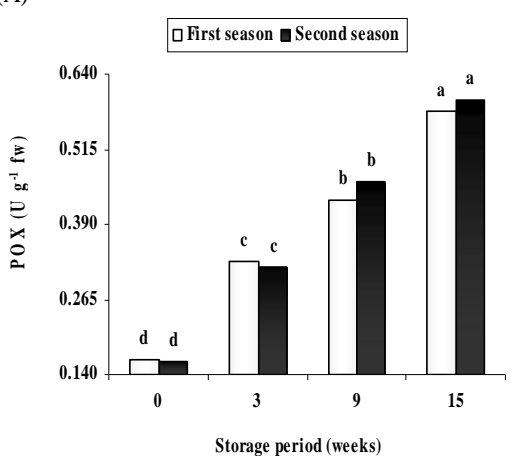

(C)

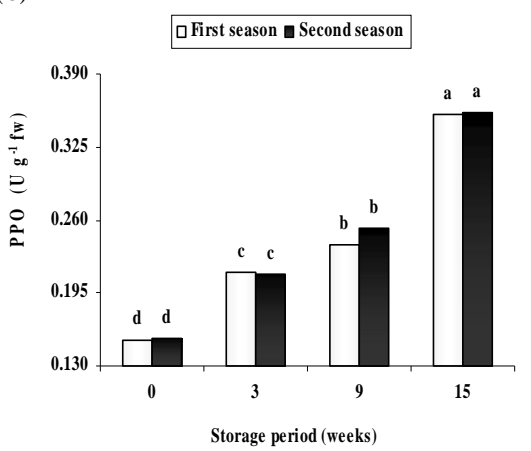

(E)

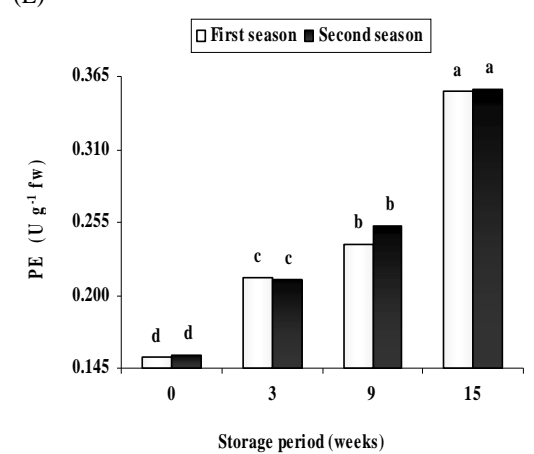

(B)

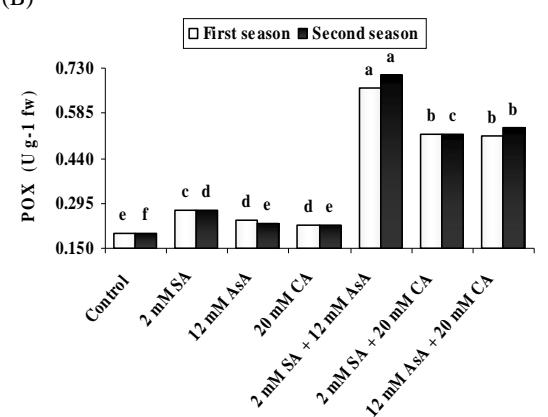

Antioxidant treatments

(D)

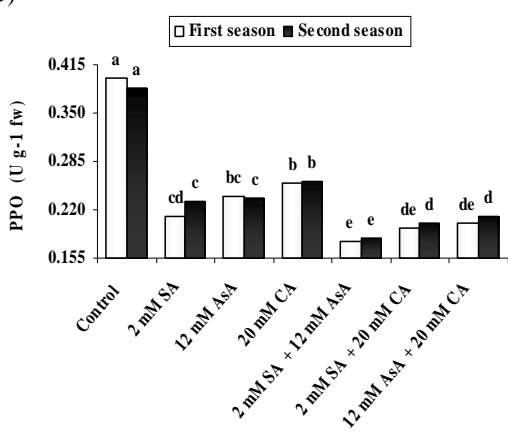

Antioxidant treatments

(F)

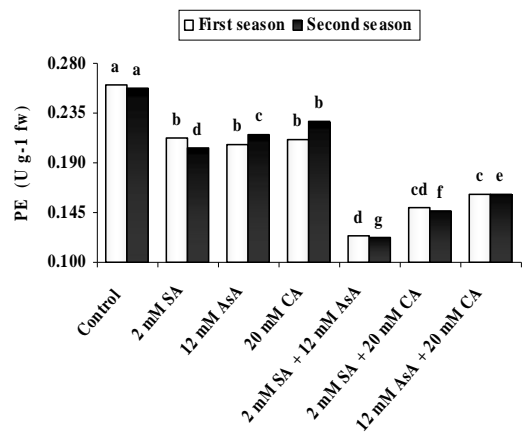

Antioxidant treatment

Figure. 3. Effect of storage period on activities of POX (A), PPO (C) and PE (E) enzymes and effect of antioxidant applications of salicylic acid (SA), ascorbic acid (AsA) and citric acid (CA) solutions on activities of POX (B), PPO (D) and PE (F) enzymes of 'Valencia' orange fruits during cold storage at $5^{\circ} \mathrm{C}$ followed by one week at $18-23^{\circ} \mathrm{C}$ as marketing period.

Different letters indicate significant differences between storage periods or antioxidant treatments according to DMRT at $P \leq 0.05$.

Egypt. J. Hort. Vol. 43, No. 1 (2016) 
Fruit juice contents of ascorbic acid (AsA), soluble solids content (SSC), titratable acidity (TA) and SSC/TA ratio

Data shown in Figures 4 and 5 clearly indicated that, SSC and SSC/TA ratio gradually and significantly increased with prolonging of cold storage period at $5^{\circ} \mathrm{C}$ followed by one week shelf life at $18-23^{\circ} \mathrm{C}$ during the two seasons in this work. On contrast, fruit content of TA and AsA gradually and significantly decreased with the progress of cold storage period followed by shelf life during the two seasons in this investigation.
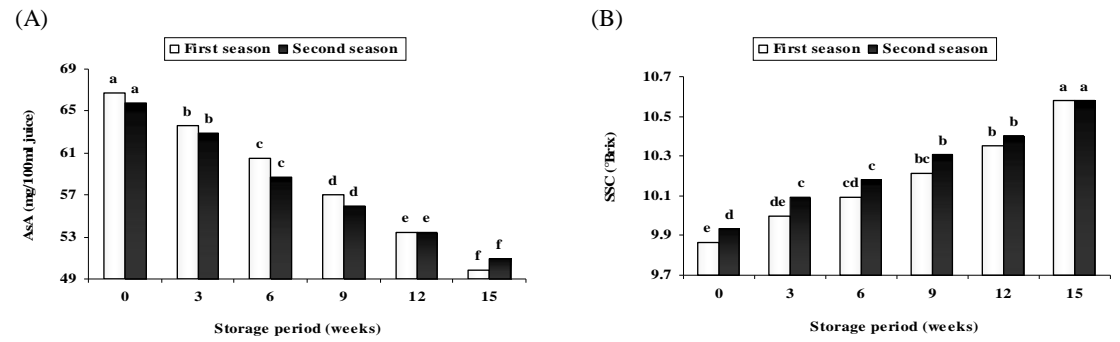

(C)

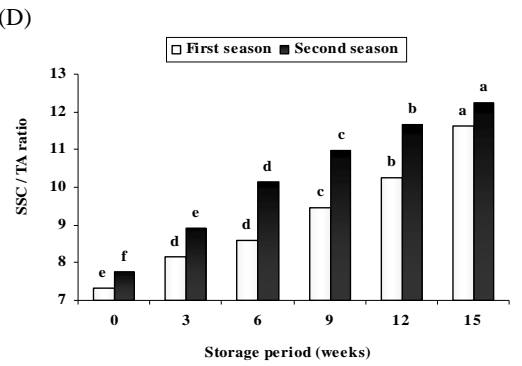

Figure 4. Effect of storage period on AsA (A), SSC (B), TA (C), and SSC/TA ratio (D) contents of 'Valencia' orange fruits during cold storage at $5^{\circ} \mathrm{C}$ followed by one week at $18-23^{\circ} \mathrm{C}$ as marketing period.

Different letters indicate significant differences between storage periods according to DMRT at $P \leq 0.05$.

Data also indicated that, all postharvest treatments studied under this investigation significantly decreased loss of fruit contents of AsA and TA as well as delayed the increase of SSC and SSC/TA ratio as compared to untreated fruits during cold storage all these characteristics. Moreover data cleared that, postharvest treatments of $2 \mathrm{mM} \mathrm{SA}$ in combination with $12 \mathrm{mM}$ AsA followed by $2 \mathrm{mM}$ SA in combination with $20 \mathrm{mM}$ CA had the most positive effects in this respect as compared to the other treatments in the two seasons in this work.

The decreasing rate of fruit juice content in TA might be due to the degradation of citric acid during storage or their conversion into sugars and further utilization in metabolic process in the fruit (Rathore et al., 2007). 
Therefore, the increase of AsA and TA by immersed 'Valencia' orange fruits in antioxidant solutions especially $2 \mathrm{mM} \mathrm{SA}$ in combination with $12 \mathrm{mM}$ AsA or $20 \mathrm{mM}$ CA treatments could be attributed to the lowest degradation of citric acid as compared to untreated fruits during cold storage period at $5^{\circ} \mathrm{C}$ followed by one week at ambient temperature.

(A)

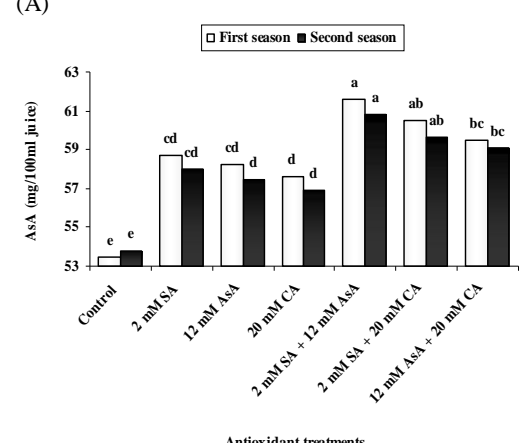

(C)

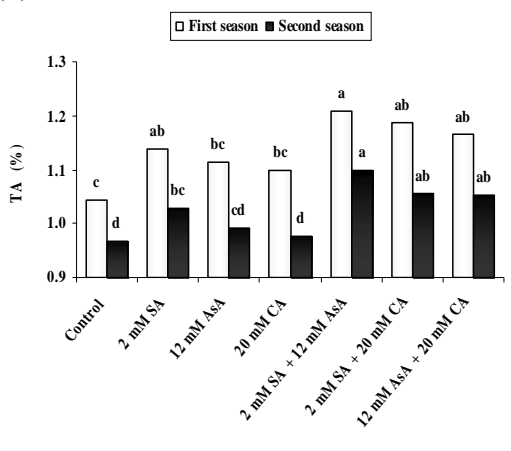

(B)

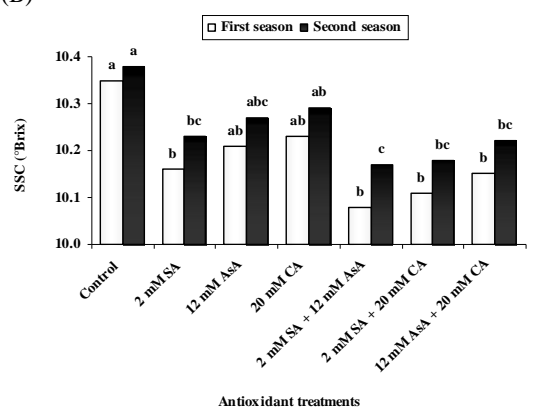

(D)

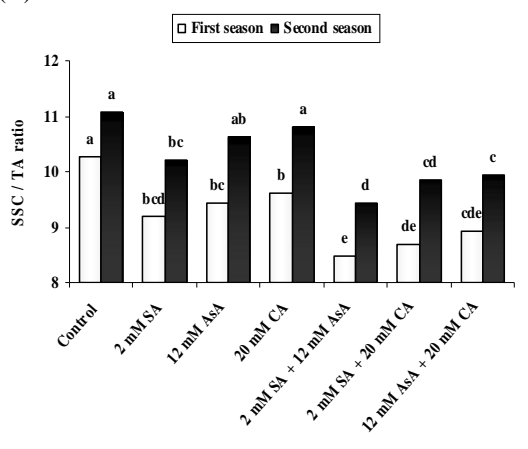

Figure 5. Effect of antioxidant applications of salicylic acid (SA), ascorbic acid (AsA) and citric acid (CA) solutions on AsA (A), SSC (B), TA (C) and SSC/TA ratio (D) contents of 'Valencia' orange fruits during cold storage at $5^{\circ} \mathrm{C}$ followed by one week at $18-23^{\circ} \mathrm{C}$ as marketing period.

Different letters indicate significant differences between antioxidant treatments according to DMRT at $P \leq 0.05$.

These results are in agreement with the findings of Lu et al. (2011) on pineapple fruits Samaan et al. (2011) on mangoes, Sayyari et al. (2011) on pomegranates and Abd El-khalek (2012) and El-Abbasy et al. (2013) on lemons,. They postulated that, postharvest treatment of SA or AsA decreased loss of fruit content in TA as compared to untreated fruits during storage period. In addition, our results are in accordance with the findings of Aghdam et al. (2011) on kiwifruits, Samaan et al. (2011) on mangoes and Abd El-khalek (2012) and ElAbbasy et al. (2013) on lemons. They claimed that, treated fruits with SA or AsA Egypt. J. Hort. Vol. 43, No. 1 (2016) 
significantly slowed the increase of fruit contents of SSC and SSC/TA ratio in comparison to untreated fruits during cold storage. Similarly, antioxidant applications of SA and AsA maintained fruit content of AsA as compared to untreated fruits during storage period in lemons (Abd El-khalek, 2012 and ElAbbasy et al., 2013), oranges (Huang et al., 2008) mangoes (Lo'ay, 2010 and Samaan et al., 2011), kiwifruits (Aghdam et al., 2011), pineapple (Lu et al., 2011) and pomegranates (Sayyari et al., 2009). Meanwhile, AsA content could be negatively related to chilling injury symptoms (Paull \& Chen, 2003).

In conclusion, antioxidant applications of SA, AsA, CA and their combination of 'Valencia' orange fruits especially immersed fruits in especially $2 \mathrm{mM} \mathrm{SA}$ in combination with $12 \mathrm{mM}$ AsA or $20 \mathrm{mM}$ CA treatments alleviated chilling injury, reduced weight loss, controlled decay incidence, increased marketable fruit percentage and decreased loss of fruit firmness. Moreover, these treatments reduced the activities of PPO and PE enzymes besides enhanced POX enzyme activity and maintained the inner fruit quality under low temperature at for up to 15 weeks followed by one week at room temperature $\left(18-23^{\circ} \mathrm{C}\right)$.

Author contributions: A.F. Abd El-khalek conceived of study, designed the experiment and purchased the chemicals. A.F. Abd El-khalek and H.G. Elmehrat performed the experiment. Gehan. A. Mahmoud determined enzyme activities only. A.F. Abd El-khalek analyzed the data and wrote the manuscript. M.A.A Mohamed revised the manuscript.

Conflicts of interest: the authors declare that there are no conflicts of interest related to the publication of this study.

\section{References}

Abd El-khalek, A.F. (2012) Reducing chilling injury of Eureka lemon fruits during cold storage. Ph.D. Thesis. Tanta Univ., Egypt.

Aghdam, M.S., Alireza, M., Younes, M., Javad, F.M. and Mahmood, G. (2011) Methyl salicylate affects the quality of hayward kiwifruits during storage at low temperature. Journal of Agricultural Science, 3 (2), 149-156.

Allen, R.D., Webb R.P. and Schake, S.A. (1997) Use of transgenic plants to study antioxidant defenses. Free Radical Biology and Medicine, 23, 473-479.

AOAC, (1990) "Official Methods of Analysis of the Association of Official Analytical Chemists". $15^{\text {th }}$ ed. Association of Official Analytical Chemists, Arlington VA, 10581059.

Asghari, M. and Aghdam, M.S. (2010) Impact of salicylic acid on postharvest physiology of horticultural crops. Trends in Food Science and Technology, 21, 502509 . 
Ben-Yehoshua, S., Shapirom, B., Chen, Z. and Lurie, S. (1983) Mode of action of plastic film in extending life of lemon and Bell pepper fruits by alleviation of water stress. Plant Physiology, 73, 87-93.

Ben-Yehoshua, S., Peretz, J., Moran, R., Lavie, B. and Kim, J.J. (2001) Reducing the incidence of superficial flavedo necrosis (noxan) of Shamouti oranges (Citrus sinensis, L. Osbeck). Postharvest Biology and Technology, 22, 19-27.

Chongchatuporn, U., Ketsa, S. and Van Doorn W.G. (2013) Chilling injury in mango (Mangifera indica) fruit peel: relationship with ascorbic acid concentrations and antioxidant enzyme activities. Postharvest Biology and Technology, 86, 409-417.

Cohen, E., Shapiro, B., Shalom, Y. and Klein, J.D. (1994) Water loss: a nondestructive indicator of enhanced cell membrane permeability of chilling injured citrus fruit. Journal of the American Society for Horticultural Science, 119, 983-986.

Delaney, T.P., Uknes, S., Vernooij, B., Friedrich, L., Weymann, K., Negrotto, D., Gaffney, T., Gut-Rella, M., Kessmann, H., Ward, E. and Ryals, J. (1994) A central role of salicylic acid in plant disease resistance. Science, 266, 1247-1250.

Delwiche, M. and Baumgardner, R.A. (1983) Ground colour as a peach maturity index. Journal of the American Society for Horticultural Science, 110, 53-57.

Ding, Z., Tian, S., Meng, X. and XU, Y. (2009) Hydrogen peroxide is correlated with browning in peach fruit stored at low temperature. Frontiers of Chemical Engineering, 3, 363-374.

Ding, Z.S., Tian, S., Zheng, X.L., Zhou, Z.W. and Xu, Y. (2007) Responses of reactive oxygen metabolism and quality in mango fruit to exogenous oxalic acid or salicylic acid under chilling temperature stress. Physiologia Plantarum, 130, 112-121.

El-Abbasy, U.K., Mohamed, E.M., El-Aidy, A.A., Mohamed, M.A.A. and Abd Elkhalek, A.F. (2013) Impact of ascorbic acid on Eureka lemon fruits under low temperature stress. The $1^{\text {st }}$ International Conference "Food and Agriculture: New Approaches". National Research Centre, 2-4 December, 2013, Egypt. Book of Abstracts, $164 \mathrm{p}$.

El-hilali, F., Ait-Oubahou, A., Remah, A. and Akhayat, O. (2003) Chilling injury and peroxidase activity changes in fortune mandarin fruit during low temperature storage. Bulgarian Journal of Plant Physiology, 29, 44-54.

Evans, N.H., McAinsh, M.R., Hetherington, A.M. and Knight, M.R. (2005) ROS perception in Arabidopsis thaliana: the ozone induced calcium response. Plant Journal, 41, 615-626.

Fernandez S., Ribeiro, C., Raposo, M., Morais, R. and Morais, A. (2011) Polyphenol oxidase activity and colour changes of 'Starking' apple cubes coated with alginate and dehydrated with air. Food and Nutrition Sciences, 2 (5), 451-457.

Hodges, D.M. (2003) Overview: oxidative stress and postharvest produce. In: Hodges, D.M. (Ed.). Postharvesst oxidative stress in horticultural crops. Food Products Press, New York., 1-12.

Egypt. J. Hort. Vol. 43, No. 1 (2016) 
Hodges, D.M., Lester, G.E., Munro, K.D. and Toivonen, P.M.A. (2004) Oxidative stress: importance for postharvest quality. HortScience, 39, 924-929.

Horwitz, W., Senzel, A., Reynolds, H. and Park, D.L. (1975) Official Methods of Analysis of the Association of Official Analytical Chemists. 1094 p.

Huang, R.H., Liu, J.H., Lu, Y.M. and Xia, R.X. (2008) Effect of salicylic acid on the antioxidant system in the pulp of 'Cara cara' navel orange (Citrus sinensis L. Osbeck) a different storage temperatures. Postharvest Biology and Technology, 47, 168-175.

Lafuente, M.T. and Zacarias, L. (2006) Postharvest physiological disorders in citrus fruit. Stewart Postharvest Rev., 1, 1-9.

Linster, C.L. and Clarke, S.G. (2008) L-Ascorbate biosynthesis in higher plants: the role of VTC2. Trends in Plant Science, 13, 567-573.

Liu, K., Yuana, C., Chena, Y., Li, H. and Liu, J. (2014) Combined effects of ascorbic acid and chitosan on the quality maintenance and shelf life of plums. Scientia Horticulturae, 176, 45-53.

Lo'ay, A.A. (2005) Chilling injury in mangoes. Ph.D. Thesis. Wageningen Univ. ISBN: 90-8504-309-3: 1-224.

Lo'ay, A.A. (2010) Increasing the storage ability of Zibda mangoes. Journal of Plant Prod., Mansoura Univ., 1(12), 1637-1652.

Lu, X., Dequan, S., Yunhe, L., Wenqi, S. and Guangming, S. (2011) Pre and postharvest salicylic acid treatments alleviate internal browning and maintain quality of winter pineapple fruit. Scientia Horticulturae, 130, 97-101.

Mayer, A.M. (1987) Polyphenol oxidases in plants recent progress. Phytochemistry, 26, $11-20$.

McGuire, R.G. (1992) Reporting of objective colour measurements. HortScience, 27(12), $1254-1255$

Medeira, M.C., Maia, M.I. and Vitor, R.F. (1999) The first stages of pre-harvest 'peel pitting' development in 'Encore' mandarin. An histological and ultrastructural study. Annals of Botany, 83, 667-673.

M-STAT, (1993) A microcomputer program for the design, arrangement and analysis of agronomic research experiments. Michigan State University.

Paull, R. and Chen, E.C.C. (2003) Postharvest physiology handling and storage of pineapple. In: Bartholomew, D.P., Paull, R.E. and Rohrbach, K.G. (Ed.), pp. 253-279, The Pineapple: Botany, Production and Uses. CABI Publishing, New York.

Paull, R.E. and Rohrbach, K.G. (1985) Symptom development of chilling injury in pineapple fruit. Journal of the American Society for Horticultural Science, 110, 100105. 
Powell, M.R. (2003) Modeling the response of the Mediterranean fruit fly (Diptera: Tephritidae) to cold treatment. Journal of Economic Entomology, 96, 300-310.

Pressey, R. and Avants, J.K. (1973) Separation and characterization of endopolygalacturonase and exopolygalacturonase from peaches. Plant Physiology, 52, 252-256.

Rathore, H.A., Masud, T., Sammi, S. and Soomro, H.A. (2007) Effect of storage on physico-chemical composition and sensory properties of mango (Mangifera indica $\mathrm{L}$.) variety Dosehari. Pakistan Journal of Nutrition, 6 (2), 143-148.

Samaan, L.G., El-Dengawy, E.F.A. and, El-Fayoumy, Heba M. (2011) Effect of antioxidant treatments on behavior of 'Zibda' mango fruits cv. (Mangifera indica L.) at post-harvest and shelf life during cold storage. Journal of Plant Production, Mansoura University, 2 (7), 919-933.

Sayyari, M., Babalar, M., Kalantari, S., Serrano, M. and Valero, D. (2009) Effect of salicylic acid treatment on reducing chilling injury in stored pomegranates. Postharvest Biology and Technology, 53, 152-154.

Sayyari, M., Salvador, C., Daniel, V., Huertas, M.D.M. and Serran, M. (2011) Acetyl salicylic acid alleviates chilling injury and maintains nutritive and bioactive compounds and antioxidant activity during postharvest storage of pomegranates. Postharvest Biology and Technology, 60, 136-142.

Shoor, M. (2010) Preharvest citric acid application extended postharvest vase life of Lilium cv. Brunello. $28^{\text {th }}$ International Horticultural Congress.

Smirnoff, N. (2000) Ascorbate biosynthesis and function in photoprotection. Philosophical transactions of the royal society of London. Series b: Biological Sciences, 355, 1455-1464.

Steel, R.G.D., Torrie, J.H. and Diskey, D.A. (1997) "Principles and Procedures of Statistics. A Biometrical Approach", $3^{\text {rd }}$ ed. McGrow-Hill Publishing Company, New York, USA, 336-376.

Tareen, M.J., Abbasi, N.A. and Hafiz, I.A. (2012a) Effect of salicylic acid treatments of storage life of peach fruits cv. 'Flordaking'. Pakistan Journal of Botany, 44 (I), 119124.

Tareen, M.J., Abbasi, N.A. and Hafiz, I.A. (2012b) Postharvest application of salicylic acid enhanced antioxidant enzyme activity and maintained quality of peach cv. 'Flordaking' fruit during storage. Scientia Horticulturae, 142, 221-228.

Valero, D. and Serrano, M. (2010) Postharvest biology and technology for preserving fruit quality. CRC-Taylor and Francis, Boca Raton, USA.

Voss, D.H. (1992) Relating colourimeter measurement of plant colour to the royal horticultural society colour chart. HortScience, 27 (12), 1256-1260.

Watkins, C. and Harman, J. (1981) Use of penetrometer to measure flesh firmness of fruit. Orchadist, N.Z., 14-16.

Egypt. J. Hort. Vol. 43, No. 1 (2016) 
Xu, X. and Tian, S. (2008) Salicylic acid alleviated pathogen induced oxidative stress in harvested sweet cherry fruit. Postharvest Biology and Technology, 49, 379-385.

Yang, Z.F., Cao, S.F., Zheng, Y.H., Jiang and Y.M. (2012) Combined salicylic acid and ultrasound treatments for reducing the chilling injury on peach fruit. Journal of Agricultural and Food Chemistry, 60, 1209-1212.

Yao, H.J. and Tian, S.P. (2005) Effects of pre- and postharvest application of SA or MeJA on inducing disease resistance of sweet cherry fruit in storage. Postharvest Biology and Technology, 35, 253-262.

Zheng, Y. and Zhang, Q. (2004) Effects of polyamines and salicylic acid postharvest storage of 'Ponkan' mandarin. Acta Horticulturae, 632, 317-320.

(Received 29/ 2/ 2016; accepted 31/ 5/ 2016)

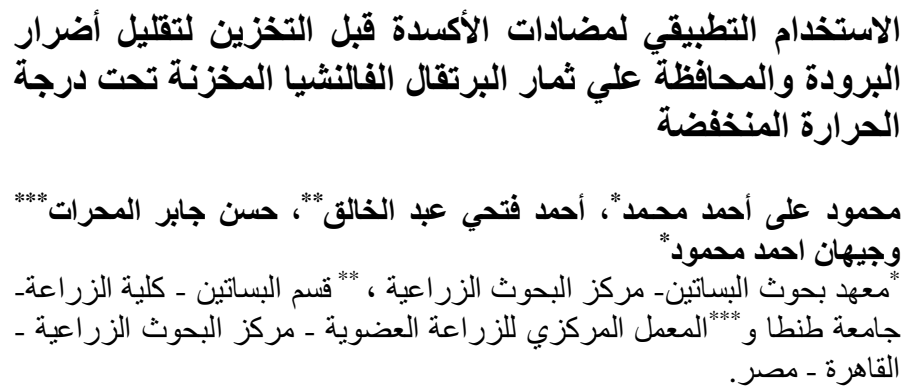

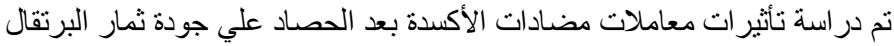

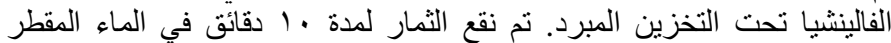

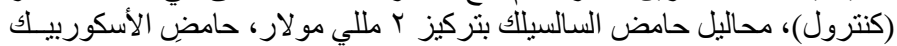

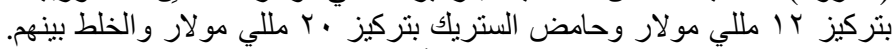

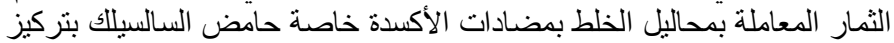

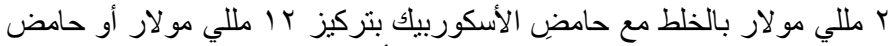

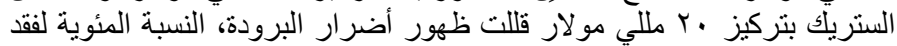

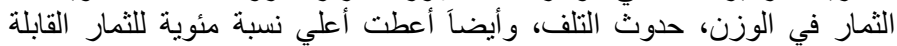

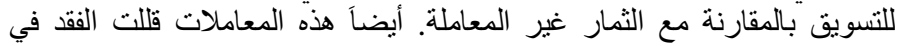

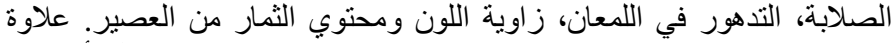

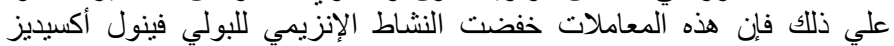

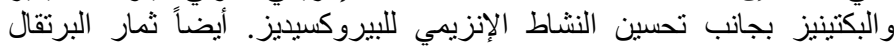

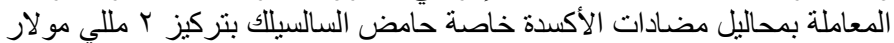

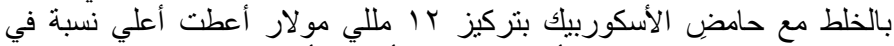

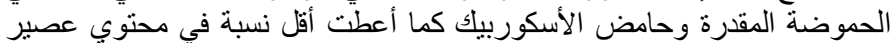

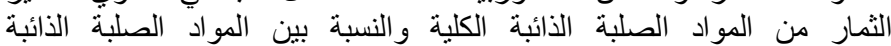

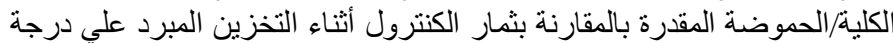

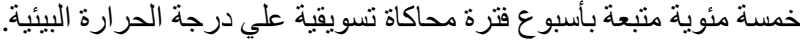

